\title{
Preclinical Medical Students' Awareness About Disabled Friendly Campus
}

\author{
Selin Davun ${ }^{1}$, Merve Kurnaz Ay ${ }^{\circledR}$, Melda Karavus ${ }^{1}$, Fatma Kilvan $^{2}$, Irem Kuralay ${ }^{2}$, Burce Akbagra ${ }^{\circledR}$, Onur Akalin ${ }^{2}$, \\ Seyhan Hidiroglu ${ }^{1}$ \\ ${ }^{1}$ Marmara University, School of Medicine, Department of Public Health, İstanbul, Turkey \\ ${ }^{2}$ Marmara University Faculty of Medicine, İstanbul, Turkey
}

Correspondence Author: Selin Davun

E-mail: slnblc@hotmail.com

Received: 28.02.2021 Accepted: 05.05.2021

\begin{abstract}
Objective: The "Disabled Friendly Campus" is relatively new consept in the world. In this study we aimed to evaluate the awareness of preclinical medical students about the Disabled Friendly Campus.

Methods: Cross-sectional study was conducted at a public university's Faculty of Medicine Campus. In our study, 362 students were included and the data were obtained between March and June 2019. A questionnaire was prepared in the light of the literature. In the first part of the questionnaire, socio-demographic features were questioned; In the second part of the questionnaire there were 13 questions about the arrangements required for a disabled person on a campus. Answer options such as $1=1$ don't agree, $2=1$ have no idea and $3=1$ agree. The score varied between 13-39, and as the total score obtained increases, it was assumed that the awareness of Disabled Friendly Campus will increase.

Results: In our study 3.3\% ( $n=12)$ of the participants had any disability, and $18.2 \%(n=66)$ had a disabled person in their family. A statistically significant difference was observed between the participants' disabled friendly campus awareness scores according to their gender, class, their participation in an activity related to disabled people and whether they found their campuses suitable for disabled people.

Conclusion: It can be suggested that the questionnaire, which is assumed to evaluate the awareness of preclinical medical students on Disabled Friendly Campus, can be made into a scale with high validity and reliability.

Keywords: Students, Medical Faculty, Disabilities.
\end{abstract}

\section{INTRODUCTION}

Disability is an unfavorable situation that prevents or limits an individual from performing the activities that are expected to be done according to age, gender, social and cultural status as a result of an injury or disability. Disability causes both the disabled individual and the person responsible for their care to be affected physically, emotionally and socially, and therefore to be exposed to various problems (1). The problems of people with disabilities are a global human rights problem and it is known that disabled people have problems in terms of social integration in our country (2).

According to World Health Organization (WHO), it is observed that approximately $10 \%$ of the world's population is disabled and this rate reaches $15 \%$ in some countries (3). In our country, according to the data of Turkey Statistical Institute, $12 \%$ of our population is composed of people with disabilities. Accordingly, it is understood that approximately 8.5 million disabled people live in our country (4).

Universities are institutions that direct the future of countries, train various professionals who have an important place in the society, enable entrepreneurial individuals to emerge, and aim to make these individuals useful to the society in every sense. University education broadens individuals' horizons, paves the way for new ideas and plays an active role in shaping the future (5). The settlements that describe the university areas are called "campus" in general definition. Students spend most of their time in campus areas while studying at the university. Campuses are a living environment. All the educational, physical and social needs of the students should be met in a campus area. It should be one of the main features of a campus to access common areas for disabled students and to be able to use it with nondisabled individuals. The disabled individual will only feel more normal and comfortable under these conditions (6).

As suggested by Brown (1995) and Olkin (2002), disability should be perceived as a social structure in which the problems arising from disability are focused on the inability of the environment to adapt to the needs of the disabled rather than a defect within individuals by nature (7). Nevertheless, negative attitudes and limited physical access are typical obstacles that prevent people with disabilities from fulfilling 
their desired roles in society. The awareness of disability perceived from the cultural and social paradigm is a step towards removing these social and environmental barriers to ensure the full social, physical and spiritual participation of persons with disabilities in society (8).

Wilson and Lieberman (2000) stated the main benefits of reaching disability awareness as follows; Acceptance of disabled people by others, increase in socialization experienced by disabled people, improvement of living standards of disabled people and enabling disabled people to live independently (9).

In our country, the provision of tools and equipment to facilitate the education life of disabled university students in the 15th article of the Law on the Disabled People and the Amendment of Some Laws and Decree Laws that entered into force in 2005 (Law No: 5378 Date of Adoption: 01.07.2005) Establishment of Disabled Counseling and Coordination Center to work on issues such as preparing special course materials, education, research and accommodation suitable for the disabled (10).

It is important to change the attitudes towards disabled people in a positive way for their full and effective participation in the society. Universities are one of the places where this change will take place (11). Physicians are the individuals who encounter disabled individuals most frequently and have high awareness. For this reason, first of all, it is necessary to investigate how medical faculty students evaluate disability for change.

This study was conducted to evaluate the awareness of preclinical medical faculty students about Disabled Friendly Campus.

\section{METHODS}

\subsection{Ethical Statement}

Prior to the study, Ethics Committee Approval and research permit were obtained from the Marmara University Ethics Committee with 09.2019.480 protocol number on the $3^{\text {rd }}$ May 2019 and the people who constituted the sample size of the research were asked to participate in the study after being informed about the research and permits. Our study was conducted according to the Declaration of Helsinki and written informed consent was obtained from all participants.

\subsection{Study Population}

This cross-sectional study was carried out at a Public University, Anatolian side in Istanbul province in Turkey. Time period of the research was March-June 2019. The total population of our study consists of 610 preclinical medical students. The sampling calculation was made with the unlikely quota sampling method. It is aimed to reach minimum 354 people by accepting alpha error level $5 \%$, sample power $80 \%$ and design effect 1.5. Each class was accepted as a cluster and it was planned to take participants from each cluster according to the number of students (proportional to the population). In all of participants, 127 students from 1st grade students, 116 students from 2 nd grade students and 119 from 3rd grade students were reached. A total of 362 students participated in our study. Inclusion criteria were preclinical medical students who study at the concerned public university and individuals who gave informed consent.

\subsection{Study Tool: The Questionnaire}

The students were given questionnaires before the practical lecture hour on campus, and filled in under observation. A questionnaire was applied to the participants to measure their awareness about the Disabled Friendly Campus. In the first part of the questionnaire, the socio-demographic characteristics of the students have been questioned. In the continuation of the questionnaire, whether or not he/she had a disabled friend up to now, the kind of disability the friend had; whether he/she has helped any individual with a disability to date and how he/she has assisted. Furthermore, it has been questioned whether or not he/she participated in a disabled-related activity and if so, what kind of activity he/ she attended. In the second part of the questionnaire, there were 13 questions of Likert-type group questions. In the Likert group questions (having 3 options), the participants were asked about the arrangements that should be in a campus for individuals with disabilities; Answer options were 1= I don't agree, 2= I have no idea and 3= I agree. The score that a person will get from these questions varied between 13-39, and as the total score obtained increases, the awareness of students about the disabled friendly campus were assumed to be increasing as well.

\subsection{Statistical Analysis}

Descriptive data in the study were presented with mean values and standard deviation values and frequency tables. Percentage and frequency distributions of the answers given to each question were calculated. For the statistical analysis of the data, the Chi-Square test was used to compare the classified data, and the Mann-Whitney $U$ test and Kruskal Wallis variance analysis were used to compare continuous variables that did not fit the normal distribution. The suitability of variables to normal distribution was examined using visual (histogram) and analytical methods (KolmogorovSmirnov/Shapiro-Wilk). In this study, $\mathrm{p}<0.05$ was considered as statistically significant.

\section{RESULTS}

Sociodemographic characteristics of the participants are given in Table 1 . The mean age of respondents was 20.56 $( \pm 1.28)$ years, with a range of $18-27$ years. Among these participants $51.9 \%$ are females and $48.1 \%$ are males. In our study $35.1 \%$ of the participants are 1 st grade, $32 \%$ are 2 nd grade, $32.9 \%$ are 3 rd grade students. Among all participants 
$96.7 \%$ reported not to have any disabilities; $81.8 \%$ of them reported not to have any family member with a disability.

Table 1. Sociodemographic characteristics of the participants

\begin{tabular}{|l|l|c|c|}
\hline \multirow{3}{*}{ Gender } & & $\mathbf{n}$ & $\mathbf{\%}$ \\
\hline \multirow{3}{*}{ Grade } & Female & 188 & 51.9 \\
\cline { 2 - 4 } & Male & 174 & 48.1 \\
\hline \multirow{2}{*}{ Disability Situation Of Participants } & 1st grade & 127 & 35.1 \\
\cline { 2 - 4 } & 2nd grade & 116 & 32.0 \\
\cline { 2 - 4 } & 3rd grade & 119 & 32.9 \\
\hline \multirow{2}{*}{ Being A Disabled Person In The Family } & No & 350 & 96.7 \\
\cline { 2 - 4 } & Yes & 12 & 3.3 \\
\hline & No & 296 & 81.8 \\
\cline { 2 - 4 } & Yes & 66 & 18.2 \\
\hline & Total & 362 & 100 \\
\hline
\end{tabular}

Among participants in the study $0.6 \%(n=2)$ self-reported to have a visually or auditory disability, $0.3 \%(n=1)$ to have an orthopedic disability, $1.1 \%(n=4)$ to have a mental disability (Attention deficit, autism, etc.), $0.6 \%(n=2)$ to have a chronic illness (Diabetes, Celiac, Thalassemia, Epilepsy etc.) and $0.8 \%(n=3)$ to have other kind of unspecified disability. Of the individuals who participated in our study $0.3 \%(n=1)$ had a speech disability disorder in their family, $1.7 \%(n=6)$ had a visually or auditory disability in their family, $1.7 \%(n=6)$ had an orthopedic disability in their family, $2.3 \%(n=8)$ had mental disability in their family (Attention deficit, autism, etc.), $10.2 \%(n=37)$ had a chronic illness (Diabetes, Celiac, Thalassemia, Epilepsy etc.) in their family, and 2.2\% ( $n=8)$ had other kind of unspecified disability in their family (Table 2).

Table 2. Distribution of participants by disability category

\begin{tabular}{|l|l|c|c|}
\hline \multirow{4}{*}{$\begin{array}{l}\text { Distribution Of } \\
\text { Participants By } \\
\text { Disability Category }\end{array}$} & None & $\mathbf{n}$ & $\%$ \\
\cline { 2 - 4 } & Speech Disability & 96.7 \\
\cline { 2 - 4 } & Visually or Auditory Disability & 2 & .0 \\
\cline { 2 - 4 } & Orthopedic Disability & 1 & .3 \\
\cline { 2 - 4 } & $\begin{array}{l}\text { Mental Disability (Attention } \\
\text { Deficit, Autism, Etc.) }\end{array}$ & 4 & 1.1 \\
\hline & $\begin{array}{l}\text { Chronic Illness (Diabetes, Celiac, } \\
\text { Thalassemia, Epilepsy Etc.) }\end{array}$ & 2 & .6 \\
\hline \multirow{4}{*}{$\begin{array}{l}\text { Distribution Of } \\
\text { Family Members Of } \\
\text { The Participants By } \\
\text { Disability Category }\end{array}$} & Others & 3 & .8 \\
\hline & None & 296 & 81.8 \\
\cline { 2 - 4 } & Speech Disability & 1 & 0.3 \\
\hline & Visually or Auditory Disability & 6 & 1.7 \\
\hline & Orthopedic Disability & 6 & 1.7 \\
\cline { 2 - 4 } & $\begin{array}{l}\text { Mental Disability (Attention } \\
\text { Deficit, Autism, Etc.) }\end{array}$ & 8 & 2.3 \\
\cline { 2 - 4 } & $\begin{array}{l}\text { Chronic Illness (Diabetes, Celiac, } \\
\text { Thalassemia, Epilepsy Etc.) }\end{array}$ & 37 & 10.2 \\
\hline & Others & 8 & 2.2 \\
\hline
\end{tabular}

Among 12 participants who self-reported to have some kind of disability in our study, 3 of them stated that they did not receive help for their disability, 2 of them used glasses, 1 of them used hearing aids, 1 of them used sign language, and 5 of them went to the psychiatrist and used medication. When the ways of getting help of the disabled individuals in their family, 45 of them stated that they did not receive help, 15 of them received medical help, 3 of them used assistive devices, 1 of them received special training and 4 of them received psychiatric help.

When the participants' status of having helped any disabled individual up to now and having participated in a disabilityrelated activity to date were examined, 102 of them stated that they helped at least one disabled individual up to now and 32 of them stated that they participated in an activity related to disability. When the type of the activity attended by the participants was examined, one of them stated that he/she talked at a discussion section, 25 of them participated in the sign language learning activity, two performed a book translation/outloudreading activity, and one participated in a club related to disability.

When the ways of helping friends with a language and speech disability were examined, 4 out of 10 participants stated that they helped their friends mostly with sign language; 5 of them stated that they helped socially by establishing close friendships and 1 of them stated that they guided him to get support.

Of the 28 people who stated that they helped their visual or hearing-impaired friends, 12 of them were helpful in finding directions, 8 of them helped in homework, 5 of them helped socially by establishing friendships, 3 of them learned sign language, 1 of them contributed to the production of 'we walk technology'.

Of the 20 people who stated that they helped their orthopedically disabled friend, 18 of them stated that they helped him/her in their transportation or in carrying goods, and 2 of them stated that they supported him/her by providing moral support and motivation.

Of the 57 people who stated that they helped their mentally disabled friends, 24 of them stated that they made friends and socially supported him/her, 17 of them stated that they provided psychological support, 11 of them helped in their lessons, and 5 of them stated that they provided guidance.

Of the 35 people who stated that they helped their friend with a chronic illness, 18 of them stated that they gave psychological support, 15 of them stated that they supported him/her to get medical help, and 2 of them stated that he helped in his/her lessons.

When the participants were asked about the shortcomings they noticed in their own campuses, 32\% stated problems related to transportation, $48.8 \%$ stated problems related to physical conditions (such as elevators, ramps, toilets, lecture halls, lecture materials), $1.3 \%$ stated problems related to proper diet, and $50 \%$ did not have an opinion on this issue.

When asked about the participants' suggestions about their own campuses, they stated that there should be regulations for course materials (such as books for the visually impaired, written videos for the hearing impaired), transportation conditions (such as on-campus bus), physical conditions (such as automatic door, toilets, disabled elevator), appropriate diet ( vegan, gluten-free), and should have sign language 
interpreters, should inform people and staff, and need to organize training on this subject.

The distribution of the answers given by the participants to the awareness questions about the disabled friendly campus is given in Table 3.

Table 3. Distribution of the answers given to the awareness questions about the disabled friendly campus

\begin{tabular}{|c|c|c|c|}
\hline \multirow{4}{*}{$\begin{array}{l}\text { 1. Every university must have a disabled } \\
\text { student representative. }\end{array}$} & & \multirow{2}{*}{\begin{tabular}{|l|}
$n$ \\
11 \\
\end{tabular}} & \multirow{2}{*}{\begin{tabular}{|l|l|}
$\%$ \\
3,04 \\
\end{tabular}} \\
\hline & 1)I don't agree & & \\
\hline & 2)I have no idea & 25 & 6,91 \\
\hline & 3)I ag & 326 & 90,06 \\
\hline \multirow{3}{*}{$\begin{array}{l}\text { 2. Students with disabilities should be } \\
\text { included in the decision process for } \\
\text { adaptations to be made for them on } \\
\text { campus. }\end{array}$} & & & 1,93 \\
\hline & 2)I ha & 16 & 4,42 \\
\hline & 3)I agree & 339 & 93,65 \\
\hline \multirow{3}{*}{$\begin{array}{l}\text { 3. The physical environment of } \\
\text { universities should be arranged in a } \\
\text { way that disabled students can also } \\
\text { benefit. }\end{array}$} & 1)I dc & 4 & 1,10 \\
\hline & & 10 & 2,76 \\
\hline & 3)I agree & 348 & 96,13 \\
\hline \multirow{3}{*}{$\begin{array}{l}\text { 4. The academic environment of } \\
\text { universities should be arranged in a } \\
\text { way that disabled students can also } \\
\text { benefit. }\end{array}$} & & 6 & 1,66 \\
\hline & 2)I have no idea & 9 & 49 \\
\hline & 3)I agree & 347 & 95,86 \\
\hline \multirow{3}{*}{$\begin{array}{l}\text { 5. Separate living areas should not } \\
\text { be created for disabled students, } \\
\text { dormitory, laboratory, classroom, } \\
\text { library, toilet, etc. should be made } \\
\text { available to everyone. }\end{array}$} & 1)I dc & 22 & 6,08 \\
\hline & & & 7,18 \\
\hline & & 314 & 86,74 \\
\hline \multirow{3}{*}{$\begin{array}{l}\text { 6. Teachers must also have sufficient } \\
\text { knowledge in the field of disability in } \\
\text { order to enable the disabled student in } \\
\text { the classroom to follow the lesson. }\end{array}$} & & & \\
\hline & & & \\
\hline & 3)I agree & 32 & 88,67 \\
\hline \multirow{3}{*}{$\begin{array}{l}\text { 7. Course materials should be delivered } \\
\text { to disabled students in a way that they } \\
\text { can use. }\end{array}$} & 1)I do & 8 & 2,21 \\
\hline & 2)I ha & & 3,87 \\
\hline & & & 93,92 \\
\hline \multirow{3}{*}{$\begin{array}{l}\text { 8. Various software and hardware } \\
\text { should be provided for disabled } \\
\text { students to continue their education } \\
\text { equally. }\end{array}$} & 1)I d & & 2,76 \\
\hline & 2) l h & & \\
\hline & 3)I a & 340 & 93,92 \\
\hline \multirow{3}{*}{$\begin{array}{l}\text { 9. There should be some special diet } \\
\text { food in the cafeteria, canteen. }\end{array}$} & & & 3,04 \\
\hline & 2)I h & & \\
\hline & & & \\
\hline \multirow{3}{*}{$\begin{array}{l}\text { 10. There should be a shuttle buses on } \\
\text { the campus that disabled students can } \\
\text { also ride. }\end{array}$} & 1)Ic & & 3,04 \\
\hline & 2)I hav & & 6,35 \\
\hline & 3)। ag! & & 90,61 \\
\hline \multirow{3}{*}{$\begin{array}{l}\text { 11. Each campus must have an } \\
\text { accessible resource office that can } \\
\text { convert printed course materials into } \\
\text { accessible formats. }\end{array}$} & 1)Id & 6 & 1,66 \\
\hline & 2)I have no idea & & 7,46 \\
\hline & 3)I agree & 329 & 90,88 \\
\hline \multirow{3}{*}{$\begin{array}{l}\text { 12. The disabled friendly campus } \\
\text { unit of the school should inform the } \\
\text { instructors about the course and } \\
\text { exam adaptations that students with } \\
\text { disabilities may need. }\end{array}$} & 1)I don't agree & & 1,93 \\
\hline & 2)I have no idea & & 6,91 \\
\hline & 3)I agree & 330 & 91,16 \\
\hline \multirow{3}{*}{$\begin{array}{l}\text { 13. School administrative staff should } \\
\text { also be informed in line with the needs } \\
\text { of students with disabilities. }\end{array}$} & 1)I don't agree & 0 & 2,21 \\
\hline & 2)I have no idea & & 5,25 \\
\hline & 3)I agree & 335 & 92,54 \\
\hline
\end{tabular}

When we compared the total scores of the participants from the questionnaire regarding the awareness questions according to their socio-demographic characteristics in Table 4 , the main findings were as the following: women (37.94 \pm $3.36)$ compared to men $(37.25 \pm 3.93)(p<0.05)$, those who participated in a disabled - related activity $(38.66 \pm 1.60)$ and those who did not participate $(37.51 \pm 3.78)(p<0.05)$; and also 1 st graders $(37.31 \pm 3.75)$ getting statistically significantly lower scores than the 2nd $(37.98 \pm 3.22)$ and $3 r d(37.56 \pm$ $3.95)$ grades $(p<0.05)$.

Table 4. Comparison of participants' total scores on awareness questions according to their socio-demographic characteristics, having a disabled friend and participating in an disabled related activity

\begin{tabular}{|c|c|c|c|c|c|}
\hline & & $n$ & Mean & $\mathrm{Sd}$. & $p$ \\
\hline \multirow[t]{2}{*}{ Gender } & Women & 188 & 37.94 & 3.36 & \multirow[t]{2}{*}{0.005} \\
\hline & Men & 174 & 37.25 & 3.93 & \\
\hline \multirow[t]{3}{*}{ Class } & $1^{\text {st }}$ grade & 127 & 37.31 & 3.75 & \multirow{3}{*}{0.003} \\
\hline & $2^{\text {nd }}$ grade & 116 & 37.98 & 3.22 & \\
\hline & $3^{\text {rd }}$ grade & 119 & 37.56 & 3.95 & \\
\hline \multirow[b]{2}{*}{$\begin{array}{l}\text { Disability status of the } \\
\text { participant }\end{array}$} & Yes & 12 & 37.33 & 3.82 & \multirow[t]{2}{*}{0.806} \\
\hline & No & 350 & 37.62 & 3.66 & \\
\hline \multirow[b]{2}{*}{$\begin{array}{l}\text { Disability in the family of the } \\
\text { participant }\end{array}$} & Yes & 66 & 38.00 & 2.30 & \multirow[t]{2}{*}{0.543} \\
\hline & No & 296 & 37.52 & 3.89 & \\
\hline \multirow[b]{2}{*}{ Having a disabled friend } & Yes & 261 & 37.60 & 3.64 & \multirow[t]{2}{*}{0.775} \\
\hline & No & 101 & 37.64 & 3.73 & \\
\hline \multirow[b]{2}{*}{$\begin{array}{l}\text { Availability of the participant } \\
\text { to assist a disabled person }\end{array}$} & Yes & 102 & 37.58 & 4.01 & \multirow[b]{2}{*}{0.760} \\
\hline & No & 260 & 37.62 & 3.52 & \\
\hline \multirow[b]{2}{*}{$\begin{array}{l}\text { Participant's status of } \\
\text { participating in an activity } \\
\text { related to persons with } \\
\text { disabilities }\end{array}$} & Yes & 32 & 38.66 & 1.60 & \multirow[b]{2}{*}{0.004} \\
\hline & No & 330 & 37.51 & 3.78 & \\
\hline \multirow{2}{*}{$\begin{array}{l}\text { Situation of the participant to } \\
\text { see his / her campus suitable } \\
\text { for people with disabilities }\end{array}$} & Yes & 72 & 35.78 & 6.24 & \multirow[b]{2}{*}{$<0.001$} \\
\hline & No & 290 & 38.07 & 2.47 & \\
\hline
\end{tabular}

No statistically significant differences were observed between the participants' status of being disabled, having a disabled family member, having a disabled friend, having helped a disabled person up to now and their average awareness scores ( $p>0.05)$.

When the socio-demographic characteristics of the participants were compared with having helped a disabled individual up to now, it was found that those with a disabled friend (38.7\%) were statistically significantly more helpful than those without a disabled friend (1.0\%) $(p<0.05)$.

No statistically significant difference was found between helping any disabled individuals up to now and gender, class, disability status of the participants, and the disability status of the family of the participant ( $p>0.05)$. 
When the participants' attending a disabled - related activity was examined according to the socio-demographic characteristics, it was found that the 1st graders (3.9\%), the 2 nd graders $(12.1 \%)$ and the 3 rd grades $(10.9 \%)$ were statistically significantly less involved ( $p<0.05)$.

No statistically significant difference was found between participating in a disabled - related activity up to now and with gender, disability status of the participants, the disability status of the family of the participant and having a disabled friend ( $p>0.05)$.

No statistically significant difference was found between seeing their own campus suitable for disabled individuals and with gender, class, disability status of the participants, the disability status of the family of the participant and having a disabled friend ( $p>0.05)$.

\section{DISCUSSION}

Universities are institutions that shape the future of a community and enable the students to become beneficial to society. There is no doubt that individuals with disabilities have the right to receive education in the field they wish and to benefit from other opportunities offered by universities, just like their peers without disabilities. The society we live in, will be complete with the establishment of institutions that include the disabled, making environmental arrangements that help them to maintain their independent lives, and equal access to educational Opportunities (12). This is possible by accepting and valuing people with physical, emotional, cultural and mental disabilities as others (13). Awareness as a factor that is affected by all these processes is seen as a concept that needs to be focused on and researched (14).

In our study, a statistically significant difference was found between male and female participants in terms of awareness scores. According to a study conducted at Kırıkkale University Faculty of Health Sciences on the attitudes of university students towards disabled individuals, there was a statistically significant difference between male and females in terms of scale scores (1). In the study conducted by Altıparmak et al. a statistically significant difference was observed when scores and gender were compared.

According to a study conducted at the Malaysian university, it was found that there is no relationship between gender and disability awareness level (15).

In our study, consistent with the literature, it was found that 1 st graders got statistically significantly lower scores than the 2nd and 3rd grades $(1,16)$.

In our study, no significant difference was found between the scale scores of the participants, and the status of having a disabled person in their family.

According to a study conducted in China, it has been observed that the prejudice levels of individuals with a disabled relative are lower than those who do not have a disabled relative(17).
In addition, it has been stated that being in contact or in contact with disabled individuals makes attitudes towards disabled people more positive.

In our study, when asked about the shortcomings that the participants noticed in their own campuses, almost half of them stated that there were physical conditions and then they stated problems related to transportation problems and proper diet. Similarly, according to a study conducted at Ege University, $64.6 \%$ of the disabled individuals when asked about their transportation stated that they could easily leave their homes, while $35.4 \%$ answered no to the question. When the users who answered "No" were asked about the reasons why they could not get out of their homes easily, $23.1 \%$ of the users emphasized the physical conditions such as the lack of a ramp on the edge of the stairs, and the $20.0 \%$ of the users that the entrance width of the building was inadequate (18). These results might show us that there are deficiencies in transportation and physical conditions for people with disabilities and more regulation is needed.

When we compared the total scores of the participants in our study obtained from the questionnaire regarding the awareness questions according to their socio-demographic characteristics, it was found that those who participated in a disabled-related activity got statistically significantly higher scores than those who did not. According to the research of participating in the awareness education for the disabled in the USA, it is shown that there is an improvement in the feelings and thoughts about the attitudes towards the disabled in those who have completed the education (19).

It is important to have an understanding and knowledge of how disability perceptions and human rights can be implemented. One way to do this would be to raise awareness of the barriers and opportunities that exist in the environment for different people with disabilities (20).

The work of health professionals is directly influenced by somatopsychological attitudes. Expectations from the disabled, healthcare professionals and society play an important role in disability adaptation. Since our study was conducted with the students of a health-related department, a high level of awareness is expected. Tracking students longitudinally throughout their education and professional business life will also collect information on how the awareness of disabled people will change or not (21). We think that future research should include a more robust sample size.

The strengths of this study are that there is no previous study on this subject in the literature, so we think that our study will make significant contributions to the literature. In addition, in recent years, disadvantaged individuals are encouraged to be brought into our universities in our country and in the world. In this sense, universities are rewarded, especially in our country. Our study is also a study that emerged as a result of the efforts in this field at our University. 


\section{Limitations}

If we look at the limitations of our study, first of all, having done it in a limited population of preclinical medical school students may not reflect all medical faculty students. They may not have wanted to talk about their disability or the disabled individuals in their family, as disability can be a problem for this age group and they fear stigmatization. As it is a cross-sectional study, people with disabilities may not have been there at the time of data collection or may not have attended school that day. As the strength of our study, the fact that the study was conducted in a health-related section may have led to higher awareness.

\section{CONCLUSION}

This is a pioneering study in the field of research, and it has been carried out to ensure solidarity and awareness for all individuals, especially those with disabilities in campus life. During the literature review, it was observed that similar studies, especially measuring awareness, were very limited. With this study, it was thought that even just applying a questionnaire, an awareness could be raised on the campus and a health-enhancing step could be taken. Conducting more comprehensive and larger-scale studies on this subject will provide an opportunity for the establishment of the disabled friendly campus concept, and for all individuals to be in more cooperation and solidarity with individuals with disabilities.This pilot study enabled the researchers to plan to develop scales for measuring Disabled Friendly Campus awareness.

Ethics Committee Approval: Marmara University Clinical Research Ethics Committee granted approval for this study (date: 3/05/2019, number: 19.2019.480).

Conflict of Interest: No conflict of interest was declared by the authors.

Financial Disclosure: The authors declared that this study has received no financial support. This study was presented as a poster presentation at the 3rd International 21st National Public Health Congress held in Antalya in 2019.

\section{REFERENCES}

[1] Şahin H, Bekir H. Üniversite Öğrencilerinin Engellilere Yönelik Tutumlarının Belirlenmesi. TSA 2016; 20(3): 767-779. (Turkish)

[2] Subaşığlu, F. Üniversitelerin Bilgi ve Belge Yönetimi Bölümleri'nin "engellilik farkındalı̆̆ı" üzerine bir araştırma. BD 2008; 9(2): 399-430. (Turkish)

[3] Organization W.H. World report on disability 2011. 2011: World Health Organization.

[4] DevletistatistikEnstitüsü, T.C.B.Ö.I.v.T.C.B., Türkiye Özürlüler araştırması. Ankara: DiE, 2002.
[5] Sevinç I, Çay M. Fiziksel Engelli Bireylerin Üniversite Eğitimi Sırasında Karşılaştıkları Sorunlar (Akdeniz Üniversitesi Örneği). SUSTAD 2017; 13: 219-238. (Turkish)

[6] Yılmaz T, Gökçe.D, Şavklı F, Çeşmeci S. Engellilerin Üniversite Kampüslerinde Ortak Mekanları Kullanabilmeleri Üzerine Bir Araştırma: Akdeniz Üniversitesi Olbia Kültür Merkezi Örneği. JOTAF 2012; 9(3): 1-10. (Turkish)

[7] Olkin R. Could you hold the door for me? Including disability in diversity. Cultur Divers Ethnic Minor Psychol, 2002; 8(2): 130132.

[8] Yau Y, Lau WK. Property management, disability awareness and inclusive built environment. Emerald 2016; 34(5): 434447.

[9] Wilson S, Lieberman L. dis Ability awareness in physical education. Strategies 2000; 13(6): 12-29.

[10] Kanun, Ö.V.B.K.V.K.H.K.D.Y.H., Kanun No. 5378 Kabul Tarihi: 01.07. 2005.

[11] Çalbayram, NÇ, Aker MN, Akkuş B, Durmuş FK, Tutar S. Sağlık Bilimleri Fakültesi öğrencilerinin engellilere yönelik tutumları. Ankara Sağlık Bilimleri Dergisi 2018; 7(1): 30-40. (Turkish)

[12] ILDIZ G. Türkiyede Engelli Bireylere Yönelik Tutumlara İlişkin Çalışmaların İncelenmesi. IBAD 2018; 3(2): 599-609. (Turkish)

[13] Özyürek, M., Tutumlar ve yetersizlikten etkilenmişlere yönelik tutumların değiştirilmesi (8. Baskı). Ankara: Karatepe Yayınları, 2010. (Turkish)

[14] Altiparmak, S. and H.Y. Sari, Manisa ilinde engelli bireylere karşı toplumsal tutum. Anatolian Journal of Psychiatry/Anadolu Psikiyatri Dergisi 2012; 13(2): 110-116. (Turkish)

[15] Azizi, A.A.N., M.N. Rabun, N.A.S. Badarin. Are We Disabled among The Disabled?: Disability Awareness Among University of Malaya Students. Adm. Sci. Q. 2018; 15(1); 1-19.

[16] Thompson, T.L.C., K. Emrich, G. Moore. The effect of curriculum on the attitudes of nursing students toward disability. Rehabil Nurs 2003; 28(1): 27-35.

[17] Chan, F., et al., Differential attitudes of Chinese students toward people with disabilities: a cross-cultural perspective. Int J Soc Psychiatry 1988; 34(4): 267-273.

[18] True E. M., T.H.S., Yapılı çevrelerin fiziksel engelliler yönüyle kullanılabilirliği: İzmir Kenti Örneği. Artium 2013; 1(1): 1-16. (Turkish)

[19] Hayward L., F.-P.M.S.J., Coe M., Vargas C., Wassenar A. Examination of the short-term impact of a disability awareness training on attitudes toward people with disabilities: A community-based participatory evaluation approach. Physiother Theory Pract 2019; 37(2): 1-14.

[20] Lundälv, J., H. Ehrlington, and A. Johansen, Disability awareness arena in Sweden: voices of learning toward community facilities, universal design and disability perspective. Facilities 2020; 39(5): 217-235.

[21] Yorke, A.M., T. Ruediger, N. Voltenburg. Doctor of physical therapy students' attitudes towards people with disabilities: A descriptive study. Disability and rehabilitation 2017; 39(1): 91-97. 